\title{
THE VALUES COP-OUT AND THE CASE FOR CHARACTER DEVELOPMENT IN MORAL EDUCATION
}

\author{
MARK FREAKLEY \\ Griffith University
}

\begin{abstract}
The Review of the Queensland School Curriculum has recommended the provision of a Draft Charter of Values for Queensland schools. The values charter is intended to underpin the curriculum content and processes also recommended by the Review. In this paper it is argued that the Review's stance on values and moral education may turn out to be ineffectual because it fails to address the hard and central issue of how character is formed. The central theme is that forms of moral education which focus on the development of particular virtues are, by their very nature, action-oriented, and therefore have a better chance of affecting student behaviour than approaches confined to values education.
\end{abstract}

Many school reforms concerned with moral education concentrate on 'values talk' and shy away from the importance of character development. One of the latest instances of this reticence is to be found in the report of the Review of the Queensland School Curriculum (Wiltshire, McMeniman and Tolhurst, 1994). An important element of the report is the proposition that the curriculum should be grounded in a set of 'shared values' that are 'about what is good for both individuals and society'. The Report provides a Draft Charter of Values (see Table 1, in the appendix) which is based on research involving a consensual vision for Australia achieved by a large group of leading Australians (Campbell, McMeniman and Baikaloff, 1992).

Although this paper addresses issues concerning moral education raised by a Queensland report, these issues are not confined in Australia to the state of Queensland alone. For example, the centrality given to values education over character development in other Australian states is also clearly evident in the New South Wales and South Australian departments of education (see, for example, New South Wales Department of Education, 1987; South Australian Department of Education, 1989). At the national level, another example is the move to produce a unified approach to civics education based on the assumption that improved civic actions will come about by teaching pupils civic values along with the relevant facts about civic structures.

In his recent critique of values education, Strike claims that if we are serious about moral education we need to ask how the routine practices of schooling affect the development of character, because 'moral argument is likely to be persuasive only to those 
already possessed of good character' (1993: 5). The purpose of this paper is to explore Strike's thesis a little further and to outline some concerns about the supposed relationship between moral development and the nature of values and values education. I will begin by outlining one classical theory concerning character; then move to a critique of the values position, with examples drawn from the Queensland report; and close by sketching an alternative orientation to the general issue of moral education in schools.

But firstly some disclaimers. I do not deny that the values proposed in the Queensland values charter and in similar reports from other states are worthy principles. My argument is that moral education cannot adequately be provided for by concentrating on the teaching of values at the neglect of the development of character. Additionally, the approach to character education which will be advocated should be distinguished from the movement that goes under that name in the United States, for it too seems to emphasise the role of values teaching in the development of character; and I therefore share Lockwood's misgivings about that movements conclusion 'that there is a direct relationship between values and behaviour' (1993: 19).

\section{Aristotle on Character}

To appreciate Strike's (1993) claim we first need to unpack the notion of character. Aristotle's Nicomachean Ethics provides an excellent resource for this purpose. Aristotle's views were premised on the belief that we come to moral debates or dialogues already furnished with some knowledge about the right ways to live and he also believed that the virtues were not ideal forms but were given by the times and social worlds he experienced. So, although Aristotle was writing some 2300 years ago, his views are congruent with contemporary sociological understanding at the point where they both emphasise the social construction of practices. What Aristotle offers that is distinctive are some prescriptions about how moral practices should be brought about. Aristotle's view is that our stances on moral issues should best be seen as our advice to the young given from our position as experienced but not flawless participants in the creation and reproduction of viable ways of living. Although Aristotle's ethics is as much an explanation of why this works, an important lesson to take from reading Aristotle is that if we are concerned with moral education we must first address the issue of coming to be moral before we engage students in the construction of moral theory. In this regard, Aristotle's work contains an attractive set of proposals for anyone interested in moral education and not just the study of ethics.

According to Aristotle, the analysis of the attributes of character provides a ready explanation of moral action. A potted version of his analysis, scandalously brief as it is, follows. Character consists of the attributes of virtue and vice as possessed by all individuals. Moral virtues are acquired by practice, just as skills are, but a right act by itself is not necessarily a virtuous act. For example, a generous kind of act does not, by itself, indicate generosity but the disposition to act generously, regularly, gladly and without ulterior motive, just is the virtue of generosity. The point that virtue necessitates acting gladly is important, because it means that the virtuous life is pleasant. If on, the other hand, you do what you ought to do but not what you want to do, you struggle, then your actions are imperfect and outside of the virtuous state. A further point is that the virtuous act from the virtuous person is the product of choice, it is the exercise of the mind over conduct and over desire by an act of free will. That is why the virtuous act is pleasant for the virtuous person-it is an expression of a free will that has exercised its power through and been educated in the struggles of experience. 


\section{Problems with the Values Emphasis}

If our focus is the institution of schooling and the place of moral education, we need to ask how habituation, feeling, and cognition, that are, following Aristotle, the constitutive elements of character, are shaped by the practices to be found in schools. That is, if we assume that moral education in schools needs reforming then we need to ask what kinds of social relationships and mores, which sustain these elements, come about in schools through the content, teaching, assessment and rationale of the curriculum (both hidden and explicit) and how these should be reformed to educate for civic virtues. To ignore these questions and instead focus on values education misses Strike's (1993) point that character shapes receptivity to the purpose of improving moral practices. Given this position, I believe that the Review's interest in values will turn out to be ineffectual because it fails to address the hard and central issue of how character is formed, except in the vaguest of terms.

An example of how this failure presents itself in Queensland report is the inadequacy of its direction regarding specific social issues such as racism, sexism, and social injustice more generally. In the absence of any elaboration of how the stated values will inform and characterise stances on these issues, this approach begs the following criticism, acknowledged by the report's authors, that:

a Queensland Charter of Values capable of gaining broad acceptance across schooling sectors will, of necessity, be vague and meaningless, a collection of motherhood statements (Wiltshire, McMeniman and Tolhurst, 1994: 17).

Their way of dealing with this criticism fails to address the point; instead it suggests that these values should be utilised to frame 'reflection and dialogue among educators' regarding 'content, processes and teaching styles' and to 'translate and refine these values in terms of the particular mission of the school or system' (Wiltshire, McMeniman and Tolhurst, 1994: 6). This stance is an outcome of a further acknowledgment, made in the Report, that values are subjective and the consequence of this, in a pluralist society, that even the existence of stable metavalues will be mitigated by the many subjective and therefore equally valid value stances taken on specific issues. In the face of this dilemma, the Report's authors are driven to give up the game to the power of dialogue.

There is a necessary place for dialogue but it is at the point where together we articulate the same aspects of character towards which we hope our youth will develop. From these points of agreement we can begin to articulate the enactment of character in particular kinds of action, that is, those actions constitutive of the moral virtues or elements of character identified as the end of moral education.

The failure to incorporate such a stance becomes even more apparent when we contrast the Report's emphasis on a community-school dialogue on values, especially with regard to the formulation of appropriate responses to treatments of specific issues (e.g., racism and sexism), and the legislative authority they argue for in providing centralist syllabus formulations. It seems odd that the Report's authors should argue for the centrality of both values and knowledge in the curriculum and yet legislate only for knowledge. For instance, the Report includes the proposal that a new board of studies detail the constitutive elements of the knowledge domains that have been identified and to detail also the learning strategies to be adopted and the mechanisms for assessment. With regard to values, the Report calls for the Draft Charter of Values to be validated by state-wide discussion and debate but then interpreted in a way which suits the individual school community: 
It is most desirable that a school or system should develop a more specific and refined set of values consistent with the Charter of Values. Consequently, the Draft Charter does not name particular issues like gender equity, disability, multiculturalism or racism, or talk about violence or harassment in the school or other settings. No reading of the Draft Charter could ignore such issues, and every school has a responsibility to be responsive to them. (Wiltshire, McMeniman and Tolhurst, 1994: 18)

If the Report's authors are convinced that schools have such a responsibility then they must also have some convictions about the way such a responsibility should be exercised with regard to the issues they refer to but decline to comment on. Otherwise this responsibility is purposeless and schools remain free to be 'responsive' in any way they see fit. For example, one of the values in the Draft Charter refers to 'a need for knowledge and meaning' and commitment to 'the search for truth'. It is possible for some schools to interpret this value in such a way that Creation 'Science' will be valued at the expense of contemporary evolutionary biology. The possibility that the Draft Charter of Values can be translated and refined 'in terms of the particular mission of [such a] school' (Wiltshire, McMeniman and Tolhurst, 1994: 18) demonstrates the weakness of centralised forms of values rhetoric. Instead, a more robust approach, continuing with this example, should require any regime for the governance of schools to protect students and their teachers from any coercion to lie or otherwise misrepresent their subject matter. In this way specific issues can be addressed at the level of curriculum authority. So that, for example, schools and their teachers should be required to represent the subject matter faithfully and in accordance with the most recent advances of the discipline. As things currently stand, although there is sufficient evidence according to Speck and Prideaux for justifying state intervention in fundamentalist Christian schools in order 'to control the teaching of creation science' (1993: 293) such intervention does not take place. Institutionalising support for individual school-community responses to broadly stated values positions will do nothing to alter this but instead may help to entrench de facto policies of non-intervention.

The Report also states that 'engagement' with the Draft Charter values and not 'compliance' is being sought. Given the Review's professed grounding in wide consultation with representatives of all stakeholders, this latter point seems to be a puzzling and mistaken reading of the public interest.

At the outset of any contemporary deliberations about moral education we can be sure of some quite specific points of public agreement: we know that we need honest police, academics, teachers, politicians and bureaucrats and not people who only know about honesty while they are, at the same time, thoroughly dishonest in their actions.

Recognition of the problematic nature of values is central to understanding the basis of these criticisms. Contrary to the claims made in the Report, the problem with values is that they are attitudes more akin to feelings than beliefs. Certainly our propensity to hold certain beliefs over others will reveal our attitudes. For example, if I believe that Blacks are inferior to Whites then I reveal a racist attitude. But the appearance of attitudes alongside beliefs should not dispose us to believe that they are one and the same thing. The racist's beliefs can be tested against the world using various criteria of inferiority-it can be truth-tested. A racist attitude, on the other hand, can only be condemned as being unworthy. The strength of an attitude is most commonly revealed by the nature and extent to which its accompanying beliefs are held to have an increasingly more tenuous link with reality. In this way a sexist attitude regarding women, for example, is most obvious when its holder claims the truth for the wackiest of beliefs, such as, that because women 
have wombs it is normal for all women to want to bear children, in the face of strong evidence to the contrary.

There is one further but related problem with values which seems to go unrecognised in the Report. Though the Report's authors seem to acknowledge the subjective nature of values at the same time they believe that this should be hidden from students. For instance, they claim that:

Values clarification helps students to recognise values and to see how they are influenced by them, but should not encourage them to believe that all values are subjective and cannot be rationally justified. (Wiltshire, McMeniman and Tolhurst, 1994: 23)

But there will be many students who will wonder which values are not subjective. I wonder too given the nature of values as outlined above.

In dismissing the centrality of values, I am not advocating their total absence, however I do consider it mistaken to give centrality of place to values over considerations of character. Instead, values education should be see as one important element among others in the development of character. For example, there should be a role for feeling in educating thought, such as the Charter beliefs. Although, conversely, even in this role feeling does need to be directed by rational good will, because that is what distinguishes it from sentimentality (Midgley, 1981: 95). As Midgley so aptly puts it, 'chronic states of feeling are not just things that happen to us ... they express our choice’ (1981: 97). Most importantly, it is through the making of choices regarding actions which go against our feelings, when we seriously entertain the wisdom of less felicitous feelings, that character is developed. Therefore, moral education that has action in mind, as an end, must involve itself in assisting youth through the struggle involved in directing behaviour towards virtuous action. Because character is developed in this way through experience, or as Aeschylus bluntly claimed, 'through suffering' (Midgley, 1981: 93), schools concerned with moral education should be more explicit about providing experiences for students to develop moral character.

\section{Alternatives to the Values Focus}

Questions about the subject matter of teaching and learning, including moral education, cannot ignore the facts as we know them about how humans learn. This should be our starting point. Stevenson (1993) describes the cognitive structures (conceptual understanding, specific skills and higher order procedures) used in combination to address new, unfamiliar and atypical situations that are the ultimate tests of learning (and effective teaching). Stevenson's point is that an over-emphasis in education and training on any one of these structures will result in individuals whose capacity to address the degrees of novelty present in life's events will be diminished. This means that for any vision to be imparted by any charter of values requires, for its successful adoption by students and teachers, an elaboration of its features in terms of:

the concepts which need to be acquired to understand routine and unusual situations, the skills which are needed for action and the higher order processes needed for expertise in unfamiliar situations (Stevenson, 1993: 9).

I am in substantial agreement with these views, and believe that they could serve as a starting point for elaborating the specific elements constitutive of learning in moral education; however, the capacity of individuals to bring their cognitive structures into play on a moral issue involves more than their capacity to use their cognitive structures together with their taking a particular values stance. I illustrate this point by way of one of 
Stevenson's own examples. He argues, and I agree, that:

it is not enough to value the environment, if one cannot perceive the social forces working against conservation and does not have the capacity to use the general procedures of problem-solving, specific skills and conceptual understanding, in combination, to contribute to overcoming these forces (Stevenson, 1993: 9).

But this does not go far enough, because if these structures and this value are not learnt in an educational contexts which help develop the character of moving into action as a consequence of things learnt, or discovered, then nothing of enduring significance has been achieved. The valuing of the environment, together with the several cognitive capacities that Stevenson (1993) describes, will be to no avail if, say, competing vices of avarice or slothfulness characterise the individual in whom environmental value and the designated cognitive structures inhere. It is for this very reason that many environmental educators have advocated action research as a model for environmental education (e.g., Robottom, 1993).

In addition to the recent interest in action-oriented forms of environmental and social education, certain elements of schooling have had a long history of interest in character training. For some time individual wealthy private schools, in the Greater Public Schools tradition, have offered a credo which places this aspect of education in high regard, although, in many instances, this credo was distorted in practice by various forms of cruelty that were justified as essential to character building. For example, the horror of initiation rites, bullying, and the need to keep "a stiff upper lip" at all costs. There are, however, instances of humane schooling within this tradition where intelligence and insight have been brought to bear upon the development of more appropriate practices of character training.

Perhaps the most influential figure in this tradition is Kurt Hahn, the founder of Gordonstoun in Scotland (in Australia, Geelong Grammar was founded on the same educational principles) and the Outward Bound movement. An important feature of Hahn's approach was the use of outdoor or adventure education to provide the means whereby controlled and purposeful experiential struggle could be employed to influence character development. Although outdoor education has in recent times entered the state schooling arena, originally and overwhelmingly it has been predominantly a feature of private schooling. In a few contemporary forms, however, outdoor education has been commodified as a novelty selection of thrilling 'games' and not pursued as a method of character training. Instead, for Hahn, outdoor education was merely the vehicle by which young people could 'learn to overcome negative inclinations within themselves and prevail against adversity' (James, 1990: 7). Moreover, the resultant growth in self-discipline was not intended as a result for the individual but rather for the good of the community, as a prerequisite for civilising human communities. The social and political context in which Hahn developed his ideas - the creation of Nazi Germany and the eventual outbreak of war-was dominated by forms of authoritarianism which were efficient at galvanising the passions of young people. In opposing these practices, Hahn sought to make democratic culture stronger by making education firmly activist with the school 'operating as a community of participation and active service' (James, 1990: 10).

For our schools, both state and private, an emphasis on character training should mean that they require and reward virtuous actions. For example, schools should require and reward perseverance and tenacity in attending to tasks and not only other excellences exhibited in the performance of tasks. Kurt Hahn was little interested in the exceptional individual performance, either on the playing field or examination room, what he sought was the development to maximum potential of each pupil's disabilities. 
In seeking to reform moral education, we should ask to what extent the situations in our schools are aimed at character development in this way. Currently, I suspect, schools do not reward diligence, for instance, but individual excellence in performance, that is, the quality of work completed without regard to the effort involved. In following this line I am not suggesting that other excellences be disregarded. For example, a wrong answer is in many other respects less worthy than a correct one. However, the different ways answers are sought after and obtained are mostly dependent upon elements of character. Much of science, for example, is dependent not upon scientific workers who are foolproof at problem solving but, rather, are persistent, diligent, and skilled practitioners working together for common ends. In order to respond to the realities of work and life in a democratic culture, these issues should not be ignored but instead be made a central part of any vision for schooling. Unfortunately, the reality of contemporary schooling practices bears little resemblance to Hahn's vision of the school which 'would harmonise the social and intellectual differences between its students by operating as a community of participation and active service' (James, 1990: 10).

\section{Final Comments}

An underlying concern implicit in this paper is with what schools may attempt to avoid rather than with what they actively seek to achieve. That certain issues are not brought to the fore may be in keeping with the Draft Charter of Values, for example, I may value equity without discussing issues of gender and race because I may also value the quiet life. But avoidance is difficult if moral education consists of the full-blooded attempt to develop character. A formal education actively participating in character development, when that character is specified in terms of civic virtue cannot duck the issues which occupy the civic 'space'. If it does attempt to do so it can be criticised according to its own internal logic. Values education, on the other hand, because its moral space is subjective, can, as we have seen with values clarification, leave moral education to the individual student. In a democratic society we are affronted at the idea that our individual values should be the target of the legislature; at the same time, we recognise that our civic actions must be. It is because action is constitutive of character, but not of valuing, that character development or education should properly be seen as a concern of publicly funded forms of education, such as schooling, and values education less so or only in as far as it contributes directly to character development.

Unless the curriculum adopts a specified and appropriate stance on these issues and trains students and teachers to adopt its requisite features then the system and its schools are opting out of character development. It is not enough, for example, to empathise with oppressed peoples, and to have the cognitive structures in place to address issues of racism, one has to also act, and this also means speak, in such a way which militates against racism; if Aristotle is correct, virtue consists of acting in just such a way and with a glad heart.

Such virtues can only be developed in students by their practising these actions, consistently and persistently, within an environment which encourages and rewards such actions and which provides disincentives for departures from such courses of action. Of course moral argument ought to be an important addition to training, and taken together they both can comprise a full mural education. However, it is only through training that character of an enduring kind can be developed, and in order for this to happen systems and schools must take a stand.

Many will recoil from these suggestions. They will point to an authoritarianism which is not there. It is true that moral authority is being propounded, but in defence such an authority need not be enacted despotically. Any compulsory school curriculum worthy of 
the name will mark out the course to be 'run' and will thus authorise the progress of students down this path. If it fails to do so then we, as well as the students, can ask why bother with this course and not any one other? The alternative to this state of affairs is a commitment to one course in preference to others, and in the case of moral education a commitment to inculcating in the young those things that we do already know about the good life, and to recognise these for what they are, the practical marks for constructing, through deliberative action, a coherent and worthy life.

On Aristotle's view the purpose of ethical inquiry is a deepened commitment and improved ability to lead the good life by those who already 'care about virtue' (Sherman, 1989: 7). It is well understood what the virtues are, and that they are desirable attainments, even in our supposedly postmodern condition. In other words, as Wyschogrod (1990: 55) points out about Aristotle's position, ethics 'is concerned with things that are for the most part so'. To ignore what is so commits our youth to the despotism of ignorance. But of course we cannot make them see what is so, but we can advise them about what to look for, and to provide them with contexts and experiences which may impel them to see what is so. Isn't this what the wise do best? Or have we given up on the idea of wisdom as well?

\section{REFERENCES}

Aristotle (1915) Ethica Nicomachea. In 'The Works of Aristotle', translated by W. D. Ross Oxford: Oxford University Press.

Campbell, J., McMeniman, M., and Baikaloff N. (1992) Visions of a future Australian society: Towards an educational curriculum for 2000 AD and beyond. Brisbane: Ministerial Consultative Council on Curriculum.

Hill, B. V. (1994) An education of value.-Towards a value-framework for the school curriculum.

Volume 3, Shaping the future. Review of the Queensland school curriculum. Brisbane: Government Printer.

James, T. (1990) Kurt Hahn and the aims of education. The Journal of Experiential Education. 13, 1, 6-13.

Lockwood, A. L. (1993) A letter to character educators. Educational Leadership. 51, 3, 72-75.

Midgley, M. (1981) Heart and mind. Brighton: Harvester Press.

New South Wales Department of Education (1987) The values we teach. Sydney: NSW Government Printer.

Robottom, I. (1993) Beyond behaviourism: Making environmental education research educational. In R. Mrazek (ed.), Alternative paradigms in environmental education research. Troy: North American Association for Environmental Education.

Sherman, N. (1989) The fabric of character. Oxford, Clarendon Press.

South Australian Department of Education (1989) Our school's values: a discussion paper. Adelaide: Author.

Speck, C. and Prideaux, D. (1993) Fundamentalist education and creation science. Australian Journal of Education. 37, 3, 279-95.

Stevenson, J. (1993) A knowledge perspective on curricula for a desirable future. New Horizons in Education. 88, 3-13.

Strike, K. A. (1993). Against "values": Reflections on moral language and moral education. Education Policy Analysis Archives, 1,13. [A peer reviewed electronic journal operating as a LISTSERV under the name EDPOLYAR at ASUACD.BITNET (Internet address: ASUVM.INRE.ASU.EDU).]

Wyschogrod, E. (1990) Saints and postmodernism. Chicago, University of Chicago Press

Wiltshire, K. McMeniman, M., and Tolhurst, T. (1994) Shaping the future. Review of the Queensland school curriculum. Volume 1. Brisbane, Government Printer. 
Address for Correspondence: Mark Freakley, School of Curriculum, Teaching and Learning, Faculty of Education, Griffith University, Queensland, Australia, 4111.

\section{Table 1: Draft Charter of Values (Wiltshire, McMeniman and Tolhurst, 1994)}

Affirming a belief that each person is uniquely valuable, the Queensland curriculum will value a commitment to:

- individual self-respect and pride in identity

- honesty and personal integrity

- acceptance of, respect for, and care of others

- open-mindedness to views and experiences of others

- social justice

- each person realising his or her own potential as a human being

- initiative and enterprise

Affirming a belief that all people interdependently share stewardship

of the earth and its riches, the

Queensland curriculum will value a

commitment to:

- ecological sustainability

- economic and social development for the benefit of all

- international understanding and cooperation

- processes to shape a better future
Affirming a belief that we all share a responsibility to contribute to the welfare of our society, the Queensland curriculum will value a commitment to:

- cooperation, democratic processes, and active and informed citizenship

- ethical behaviour that is socially responsible

- recognition of, and respect for, the variety and uniqueness of what different groups bring to society

- partnership between school, home and community

- accountability for the use of social resources

Affirming a belief that all people share a need for knowledge and meaning, the Queensland

curriculum will value a commitment to:

- curiosity and questioning insight

- logical, critical and reflective thinking

- intuition and creativity

- the search for truth

- a variety of ways of knowing and of learning

- the importance of lifelong learning 